\title{
Relationship between whorls dermatoglyphic patterns and handedness amongst students of tertiary institutions in Ilorin Nigeria
}

\section{Whorls dermatoglif patinlar ve \|lorin'deki üçüncüll kurumların öğrencileri arasında el teslimi Nijerya}

\author{
${ }^{* 1}$ Kiekwe V., ${ }^{2}$ Neku R.O., ${ }^{2}$ Olawepo A
}

${ }^{1}$ Department of Anatomy, Faculty of Basic Sciences, College of Health Sciences, Benue State University Makurdi, Benue State Nigeria. ${ }^{2}$ Department of Anatomy, Faculty of Basic Sciences, College of Health Sciences University of Ilorin, Ilorin Kwara State Nigeria. Corresponding author: Vershima Kiekwe, MD, Department of Anatomy, Faculty of Basic Sciences, College of Health Sciences, Benue State University Makurdi, Benue State Nigeria.

E-mail: vkiekwe@gmail.com

Received/Accepted: November 06, 2019 /November 28,2019

Conflict of interest: There is not a conflict of interest.

\section{SUMMARY}

Dermatoglyphics connotesfriction ridges on the skin, visibleon fingers, toes, and palms of individuals. These epidermal ridges, especially finger prints have proven to be viable physical features in criminology, medical diagnosis and genetic studies. Handedness; observed as an individual's preferred use of a particular hand over the other, for daily activities has been attributed to the uneven distribution of fine motor skills between the left and right hand.

We conducted this study in a bid to assess the distribution of whorls fingerprint patterns in relation to Handedness amongst a set of students in North-Central Nigeria for Identification. The study had 279 respondents via purposive sampling approach, with 148 Left handed and 131 right handed people. Edinburgh Handedness inventory was used to evaluate handedness and respondents performed 14 uni-manual Tasks to ascertain handedness. Fingerprints were analyzed, using a laboratory magnifying lens to determine the print patterns and their distribution among the respondents, after obtaining them via the ink and paper method. Collated data was analyzed via Mini TAT Statistics for Windows (version 16) and Microsoft Office Excel 2016.

The Left hand in Right handed people had $51.6 \%$ whorls while the right hand had $50.8 \%$. Similarly, $56.8 \%$ was the distribution of whorls found on the left hand in Left handed people whereas the right hand had $60.4 \%$. T-test analysis of the obtained result showed no statistically significant relationship of the whorl fingerprint patterns and handedness ( $>0.05)$.

Keywords: Dermatoglyphics, whorls, handedness, identification.

\section{Kiekwe V. \\ Neku R.O. \\ Olawepo A.}

ORCID IDs of the authors: K.V. 0000-0003-1544-4176 N.R.O. 0000-0001-5401-692X O.A. 0000-0002-3476-1663

\section{ÖZET}


Bu çalıșmayı, Kuzey-Orta Nijerya'daki bir grup öğrenci arasında sağ veya solaklikla ilgili olarak whorls parmak izi modellerinin dağılımını değerlendirmek için yaptık. Çalışmada 148 solak ve 131 sağ elini kullanan 279 katılımcı vardı. El tercihini değerlendirmek için Edinburgh El Kullanımı Envanteri kullanıldı ve katılımcılar, el tercihini belirlemek için 14 tek elle yapılan görev gerçekleştirdi. Parmak izleri, mürekkep ve kağıt yöntemiyle elde edildikten sonra, baskı desenlerini ve yanıtlayıcılar arasındaki dağılımını belirlemek için bir laboratuvar büyüteç merceği kullanılarak analiz edildi. Harmanlanmıș veriler, Windows için Mini TAT İstatistikleri (sürüm 16) ve Microsoft Office Excel 2016 aracılığıyla analiz edildi.

Sağ elini kullananlarda sol elde \%51,6, sağ elde \%50,8 tur sayısı vardı. Benzer şekilde solak kişilerde sol elde bulunan sarmalların dağılımı \%56.8, sağ elde ise \%60,4'tü. Elde edilen sonucun t-testi analizi, whorl parmak izi desenleri ile el kullanımı arasında istatistiksel olarak anlamlı bir ilişki göstermedi ( $\mathrm{p}>0.05)$.

Anahtar sözcükler: Dermatoglifikler, sarmallar, el tercihi, özdeşleşme.

\section{INTRODUCTION}

The term dermatoglyphics; coined from the words "derma" meaning skin and "glyphic" meaning carving connotes the scientific study of epidermal ridges (papillary peaks, traceries of fine ridge) patterns seen on fingers (as finger prints) and on palms (as palm prints). The composition and arrangement of these ridges is always discrete and particular to each individual and is believed to have potent genetic influence (Gutierezet al., 2012). Individual dermatoglyphic patterns remain uninfluenced by external factors after birth (Naffah, 1977), hence; the ridges formed along with their characteristic composition on fingers and palms are often discrete, undeviating and will remain unaltered all through life. Subsequently, the scientific evaluation of palm and finger print patterns has been viable towards individuals' identification (Tay, 1979), medical diagnosis (Oladipoet al., 2007 and 2010). Gungadin (2007)reiterates the infallibility of individual identification via fingerprints. The peculiarity of a fingerprint is often premised on the pattern of ridges, furrows, and the minutiae points present. The minutiae points are localized ridge features, visible at the point which the ridge splits into two or at its end point. (Babler, 1990).

Skin frictional ridges commence formation during the $13^{\text {th }}$ week of fetal development and are completed at the close of the $21^{\text {st }}$ week after which they remain unaltered, with a characteristic polygenic inheritance pattern (Abueet al., 2013; Manoj and Helmlata, 2012). Fingerprints are distinctive for every individual owing to the genetic determination of epidermal ridges and these patterns remain undistorted through a lifetime except an individual sustains injuries that permanently affect the fingers. Based on this premise, fingerprints have been of tremendous importance, to determine hereditary disorders and also, individuals' forensic profile (Crawford and Duggirala, 1992). Similarly, the role of dermatoglyphic patterns in segregating ethnic and sexual differences was explored as seen with (Osunwokeet al., 2008; Igbigbiet al., 1999; 2002). The formation period of fingerprint patterns coincides with a significant growth phase of various foremost organs; worthy of note is neuronal development. Thus, the ridge patterns during this sensitive period are susceptible and can be altered by a variety of abnormalities of early stage development that range from genetic disorders, such as Down Syndrome and skeletal malformations, e.g., polydactyly (Singh et al., 2016). Studies on fingerprints are still ongoing. Wang et al, 2007, have in recent times conducted studies aimed at improving the computerization of fingerprints for rapid search and matching fingerprints globally.

The division of the ridge patterns on distal phalanges of fingertips into three main groups was pioneered by Sir Francis Galton in 1892, in which he divided the patterns as:

- Arches

-Loops and

-Whorls.

Other sub-classification have since emerged over time, yet this simple basic classification has remained the baseline and is thus used by most investigators till date (Schaumann and Alter, 1976). The whorl pattern is any ridge configuration incorporating two or more triradii, with one triradius on the radial and the other on the ulnar side of the pattern. The label of the term 'Whorl' was earlier limited to configurations with ridges that were found encircling a core but was designated as the more complex patterns as 'Composites' (Schaumann and Alter, 1976). The ridges present in a plain (simple) whorl (PW) are usually structured as a sucession of concentric rings or ellipses and are referred to as concentric 
whorls (WC) (Rajangamet al., 1995). Another type configuration is seen spiraling around the core in either a clockwise or anticlockwise direction, to which the pattern is known as a double (DW) or a spiral whorl (WS) (Campell, 1998).

Handedness (observed as hand dominance) depicts the uneven distribution of fine motor skills between the left and right hand (Raymond and Pontier, 2004). Holistically it presents a feature of specialization in which an individual is inclined to the instant use of one hand for clearly defined activities as seen in writing. Hence, an individual who is found using his or her left hand to carry out daily routines requiring skill coordination such as writing, cutting, sweeping is said to be left handed whereas the opposite is the case for a right handed individual (Zoran, 1998). Research has revealed that about 85 to $90 \%$ of the world population in estimate is right handed implying that just over 10 to $15 \%$ of the world population is left handed (Marchant and McGrew, 1998; Corballis, 1991; Zoran, 1998; Hardyck and Petrinovich, 1977). An individual's handedness is often considered to be influenced by a couple of modifications, in which some are inherent in genes that are responsible for establishing the body's left/right asymmetry (Brandleret al., 2013).

Fingerprints patterns identified to be peculiar with left/right handed individuals would be viable polygenic markers of physical anthropology for segregating left and right handed Individuals in a given population.

\section{MATERIAL AND METHODS}

\section{Study Setting and Participants}

The study had 279 participants drawn from three tertiary institutions in Ilorin, Kwara State-Nigeria. The respondents were of age 16-30 years. Ethnicity was not considered, however,only Nigerians participated. Ethical consideration was sought and subsequently approved accordingly by the University of Ilorin's ethical review authority. We had 148 respondents; predominantly left handed people and 131 respondents, predominantly right handed people who constituted the 279 respondents.

\section{Data Collection}

Handedness was determined via the Edinburg Handedness Inventory. Respondents performed (14) unimanual tasks, (preferred hand for writing, using a comb, sweeping, drawing, throwing, holding a spoon, using a scissors, using a knife, striking matches, painting, holding a tooth brush, opening a box, threading needle, using a key) (Oldfield, 1971). Methylated spirit wet cotton-wool wipes were used in cleaning fingers of respondents to rid them of all manner of dirt. On the whole, 2,790 fingerprints were obtained and analyzed by the Cummins method, using the designed questionnaire that had been pre-tested and standardized. Various specificationsof whorls prints; concentric, single spiral, double spiral, accidental along with composite whorls, like twin loops, central pocket loops, lateral pocket loops, crested and knot-crested loops were summarized as "Whorls." These were sorted for both hands and were presented for Left and Right handed individuals.

\section{Statistical Analysis}

Mini TAT Statistics for Windows (version 16) and Microsoft Office Excel for Windows (2016 version) were used for statistical analysis.

General frequency (\%) distribution of the 2790 fingerprints from 279 respondents was calculated and expressed in percentiles. Frequency distribution of fingerprints between left handed individuals (LHI) and Right handed individuals (RHI) was analyzed and expressed in ratios and percentiles. 


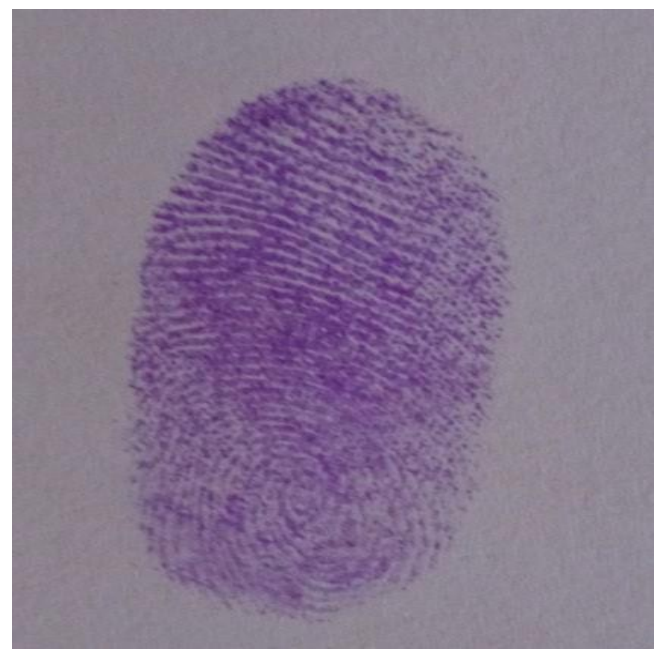

Figure 1: Picture sample of the whorl fingerprint collected.

A " $p$ " value of $<0.05$ was observed as significant (with the corresponding degree of freedom). Pearson's correlation coefficient was used in determining a possible correlation between the distribution of whorls finger print patterns in left Handed and Right Handed Individuals. Themean, Standard deviation and Standard error of mean among left and right handed individuals were evaluated. Analysis of variance
(ANOVA) and t-test were similarly conducted on the collated data from both left and right handed individuals.

\section{RESULTS}

Analyses of whorls fingerprint patterns of the left and right handed individuals are presented below.

Table 1: Table showing t-test comparing whorls fingerprint patterns of the left and right hand

Left Hand Right Hand

Left Handed

$56.8 \pm 17$

$60.4 \pm 26$

Right Handed

$51.6 \pm 20.2$

$50.8 \pm 23.3$

t-test (df)

$-0.43(8)$

$0.61(8)$

p-value

0.678

0.560

Table 2: Table showing the effect of whorls on the left and right hand

\begin{tabular}{ccccc}
\cline { 2 - 4 } & \multicolumn{2}{c}{ Left Handed } & \multicolumn{2}{c}{ Right Handed } \\
\cline { 2 - 5 } & Left Hand & Right Hand & Left Hand & Right Hand \\
Whorl & $56.8 \pm 17.9^{\mathrm{b}}$ & $60.4 \pm 26.5^{\mathrm{b}}$ & $51.6 \pm 20.2^{\mathrm{b}}$ & $50.8 \pm 23.3^{\mathrm{b}}$
\end{tabular}

Values are mean proportion ( $\%) \pm S D$ 


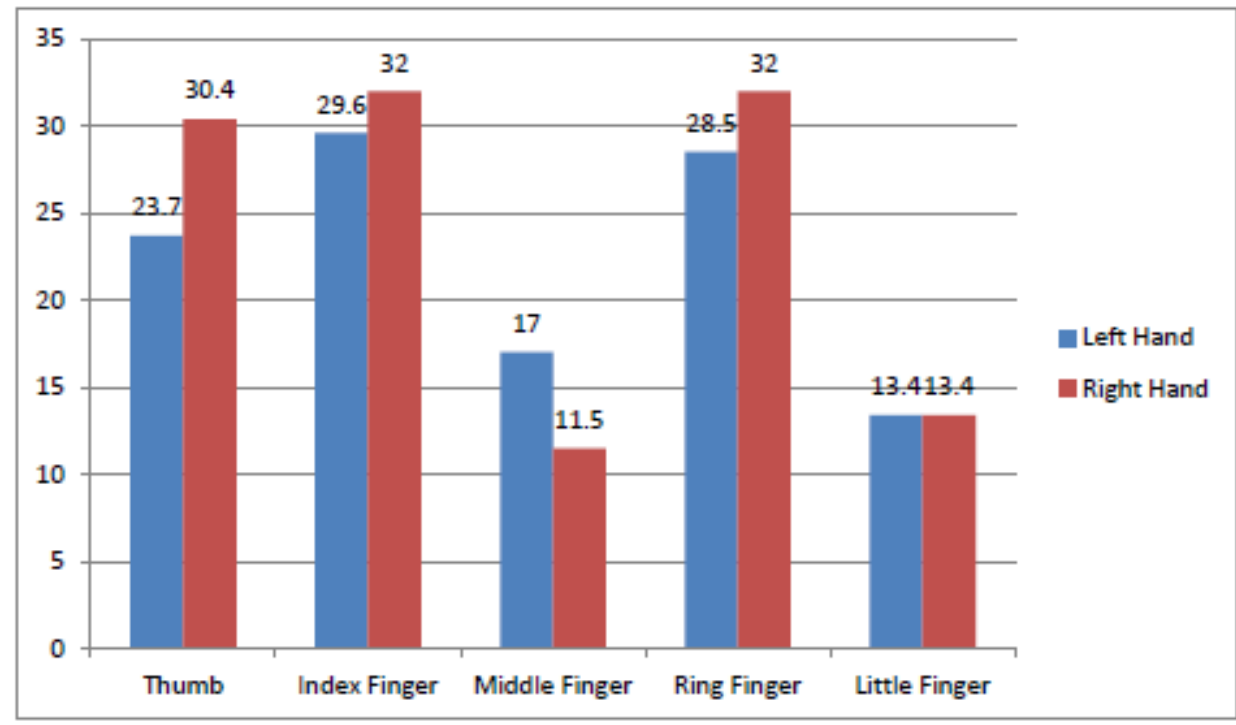

Figure 2: Bar chart showing percentage frequency distribution of whorls fingerprint patterns on the right and left hand in left handed individuals.

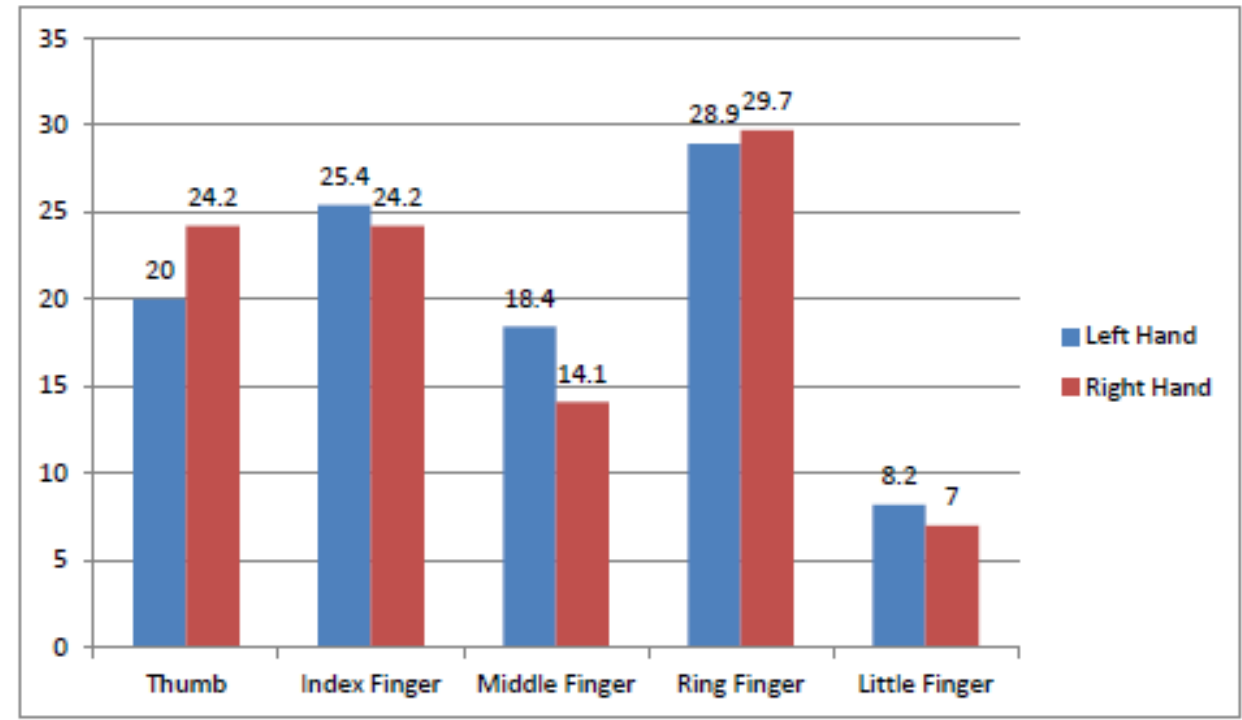

Figure 3: Bar chart showing percentage frequency distribution of whorls fingerprint patterns

on the left and right hand in right handed individuals.

Results in Table 1 has revealed that there was no significant difference in the distribution of whorl patterns in relation to handedness, implying that the mean proportion of the whorls between the left handed and right handed individuals for both hands is the same. The significance was tested using the mean proportion of the fingers.

Table 2 showed the mean proportion of whorls on the left and right hands of the left and right handed subjects. The proportion of whorls on the right hand of left handed individuals was greater than that on the right hand in right handed individuals but was not significantly different statistically. Similarly, the mean proportion whorls on the left hand of left handed individuals is higher than both hands of the right handed individuals but was not found to be statistically significant.

\section{DISCUSSION}

Globally, Anthropologists have researched extensively on fingerprints, factoring them as essential gross anatomical features in individual profiling for personal identification. Extracting Fingerprints at crime scenes, cross referencing 
with fingerprints data base in trailing suspects of crime has made studies woven around dermatoglyphics very essential in forensic analysis (Cummins H., 1935).

Our study have shown an uneven but significant distribution of whorl fingerprints pattern on the right and left fingers of both Left handed and right handed individuals which tallies with the observations of Priscilla et al., 2018.

Our findings indicated that; in left handed Individuals, the percentage whorl distribution had the Thumb with $23.7 \%$ and $30.4 \%$ for the left and right, Index finger had $29.6 \%$ and $32 \%$ for the left and right. The Middle Finger had $17 \%$ and $11.5 \%$ for the left and right fingers, the Ring finger had $28.5 \%$ and $32 \%$ for the left and right while the Little finger had $13.4 \%$ for both left and right respectively.

Whereas, in Right handed Individuals, the thumb had; $20 \%$ and $24.2 \%$ whorl distribution on the left and right thumbs. The index finger had $25.4 \%$ and $24.2 \%$ for the left and right, the Middle Finger had $18.4 \%$ and $14.1 \%$ on the left and right, The ring finger had $28.9 \%$ and $29.7 \%$ on the left and right while the little finger had $8.2 \%$ and $7 \%$ on the left and right respectively, which is consistent with the findings of Agarwal and colleagues, 2012.

\section{CONCLUSION}

There was no statistically significant relationship seen between whorls fingerprint patterns and handedness. The distribution pattern was uneven and without significant statistical differences. Therefore, the whorl fingerprint pattern may not be considered as a viable feature of physical anthropology that could be linked with handedness in the study population.

\section{LIMITATION OF THE STUDY}

The study was limited to the participants available under the purposive sampling approach owing to the security challenges in Nigeria. Therefore, prospective participants were prevented from participating actively in the study.

\section{REFERENCES}

1. Abue A., Ujaddughe M. and Kpela M. (2013). The arch pattern dermatoglyphics on the toes of Hausa ethnic group of Nigeria. Advanced Anthropology; 3(4):237-239.

2. Argawal P.S., Dutt H.K., Saxena A., 2012: General assumption of psychological behaviour based on fingerprint pattern. J Biol
Life Sci. 3(1): 59-65

3. Babler J.W. (1990). Prenatal Communalities in Epidermal Ridge Development. In; Trends in Dermatoglyphic Research edited by Norris M. Durham and Chric C. Plato, Kluwer Academic Dordrecht/London/Boston pp:54-68

4. Brandler M.W., Morris P.A., Evans D.M., Scerri T.S., Kemp J.P., Tipson J.N et al., (2013). Common Variants in Left/Right Assymmetry Genes and Pathways Are Associated with Relative Hand Skill. PloS Genet 9(9): e1003751. DOI: 10.137/journal.pgen.1003751.

5. Campbell D. Edward (1998). Fingerprints and Palmar Dermatoglyphics. Web article;

6. https://www.handanalysis.co.uk/EdCampbellPalmD-History.htm

7. Corballis M.C. (1991). The Lopsided Ape: Evolution of the Generative mind. Journal of Social and Evolutionary Systems 15 (3): 319-326.

8. Crawford M.H. and Duggirala R., (1992). Digital dermatoglyphic patterns of Eskimo and Amerindian populations: relationships between geographic, dermatoglyphic, genetic and linguistic distances. Human Biology; 64(5):683-704.

9. Cummins H. (1935): Morphology of the palmar hypothenardermatoglyphics in man. Hum Biol. 7:1-23

10. Gungadin S. (2007): Sex Determination from Fingerprint Ridge Density. Internet Journal of Medical Update: 2(2):4-7

11. Gutierez S.B., Lucenario J.L.S. and Yebes M.J.T. (2012). Dermatoglyphic studies among the Dumagat-Remontado tribal population of the Philippines. Journal of Anthropology. http//dx.doi.org/10.1155/2012/812128.

12. Hardyck C. and Petrinovich L.F. (1977). Psychological Bulletin; The American psychological Association 84(3): 385.

13. Igbigbi, P. S and Msamati, B. C. (2002): 'Palmer and Digital dermatoglyphic of indigenous black Zimbabweans. Journal of Medical Science Monitors; 8 (2): 757-761.

14. Manoj K.S. and Hemlata S. (2012). Dermatoglyphics as a diagnostic to predict diabetes. J ClinDiagan Res; 6(3):327-332.

15. Igbigbi P. S. and Msamati, B. C. (1999). 
Palmer and Digital Dermatoglyphic patterns in Malawian subjects. East Africa Medical Journal. 76 (12): 668-671

16. Marchant L.F. McGrew W.C. (1998). Human handedness: an ethological perspective.Human Evolution 13: 221-228.

17. Naffah J. (1977). Dermatoglyphic analysis: anthropological and medical aspects. Bulletin of the New York Academy of Medicine 53:681.

18. Oladipo G.S., Olabiyi O., Oremosu A.A, Noronha C.C, Okanlawon A.O and Paul C.U. (2007).Sickle-cell anaemia in Nigeria: dermatoglyphic analysis of 90 cases; African Journal ofBiochemistry Research,1 (4): 054059.

19. Oladipo,G.S., Osogba I.G., Bobmanuel I., Ugboma H.A.A., Sapira M.K., and Ekeke O.N. (2010). Palmar Dermatoglyphics in Essential Hypertension Amongst Rivers Indigenes. Australian Journal of Basic and Applied Sciences, 4(12): 6300-6305.

20. Oldfield R.C. (1971). The assessment and analysis of handedness: the Edinburghinventory. Neuropsychologia. 9 (1): 97-102.

21. Osunwoke, E. A., Ordu, K.S.. Hart, J. and Tamunokuro, F. B. (2008). A Study on the Dermatoglyphic patterns of Okrika and Ikwerre Ethnic groups of Nigeria. Scientia Africana; 7 (2):143-147.
22. Pricilla O.N.C., Samuel E. C., Sunday I. P. (2018): Dermatoglyphic patterns of female convicted criminals in Anambara State. Forensic Res Criminal Int J 4: 294-296.

23. Raymond M. and Pontier D. (2004). Is there geographical variation in human handedness?aterality 9: 35-51.

24. Rajangam S., Janakiram S., Tho,as I.M., (1995). Dermatoglyphics in Down's Syndrome.Journal o Indian Medical Association. 93(1): 10-13.

25. Schaunmann B. and Alter M. (1976). Dermatoglyphics in medical disorders. Newyork Springer verlag, Berlin; 27-87.

26. Singh A.M., Gupta R., Zaidi S.H.H. and Sigh A. (2016): Dermatoglyphics: A Brief Review.International Journal of Advanced \& Integrated Medical Sciences; 1(3): 111-112.

27. Tay, J. (1979). Dermatoglyphics in children with febrile convulsions. British Medical Journal;1111:660.

28. Wang, Y., Hu, J. and Philips, D. (2007): A fingerprint orientation Model on 2D Fourier Expansion (FOMFE) and it's application to singular-point Detection and Fingerprint indexing. IEEE Trans pattern Anal Mach Intell 29(4): 573-85

29. Zoran M. (1998). Gale Encyclopedia of Psychology, $2^{\text {nd }}$ Ed. Gale group, New York. Strickland R.S Executive Editor. pg: 419. 